\title{
The role of dividend policy in share price volatility
}

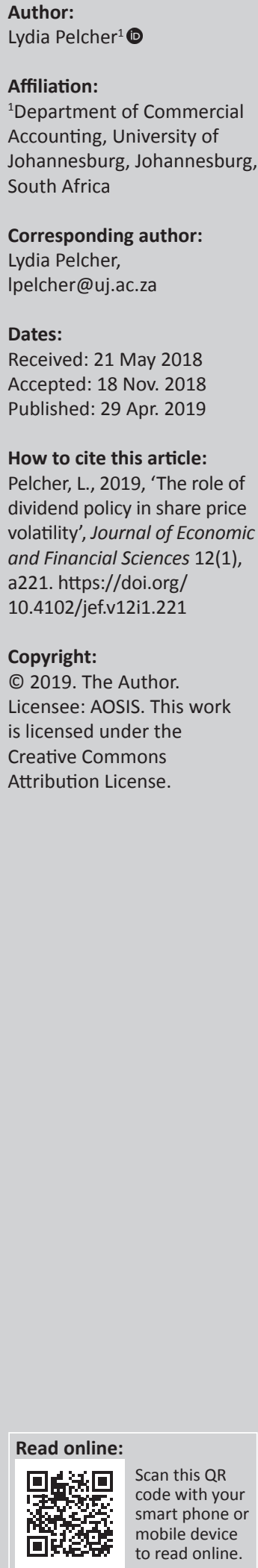

Orientation: A key objective of a company is to maximise shareholder wealth. Distribution of created wealth is achieved either through reinvestment in the company, which increases share value, or through dividend payouts. This encapsulates the dividend policy of a company. In order to realise a cash return, the former requires an investor to liquidate part of the investment, while the latter provides an immediate cash return.

Research purpose: The objective was to establish whether relationships exist between share price volatility and dividend policy for shares listed on the Johannesburg Stock Exchange Limited (JSE).

Motivation for the study: Dividend policy is an important consideration in the wealth creation process, particularly whether or not to distribute dividends to shareholders. Dividend policy is often structured to cater for shareholders' expectations.

Research design, approach and method: Panel data analysis was employed on a sample of the top 40 JSE-listed shares from 2007 to 2016.

Main findings: The results indicated that the association between share price volatility and dividend yield is positive and significant but that between share price volatility and payout ratio is insignificant.

Practical/managerial implications: Dividends were proven to be relevant to shareholders and have an association with share price volatility.

Contribution/value-add: Dividend policy for the top 40 companies listed on the JSE is a contributor to share price volatility. In order to minimise share price volatility, managers of dividend-paying companies should structure the dividend policy to have consistent dividend payments but also able to reinvest excess cash within the company.

Keywords: dividend policy; dividends; JSE; volatility; dividend payout ratio; panel data analysis.

\section{Introduction}

\section{Orientation}

The fundamental purpose of a company is to create sustainable and increased wealth for the shareholders (Mouton \& Smith 2016). This is achieved through a combination of maximising earnings and minimising risk. From an earnings perspective, wealth is increased in the form of earnings, leading to capital growth of the share, as well as the distribution of earnings through dividends (Mouton \& Smith 2016). As such, the dividend decision is important, because it is one of the avenues through which a company can achieve the objective of maximisation of wealth it creates for its shareholders. These two forms of wealth maximisation, capital growth and dividend payouts, affect the investor's choice of share investments based on investor preference (Gordon 1959).

The theoretical framework of this study is based on the competing arguments of dividend relevance versus dividend irrelevance. Lintner (1956) argued that investors believe that a company paying dividends signals information about the company to the investors, which was confirmed by Erasmus (2013) and Wolmarans (2000). This argument implies that dividend policies and decisions indeed impact share prices, because dividend payments signal information to investors, to which they react. In contrast, the third proposition of Miller and Modigliani (M\&M) stated that if a company implemented a consistent investment policy, its dividend policy would make no difference to shareholder wealth because the profit belongs to the shareholders. If the theory holds, it renders dividend payouts, and ultimately dividend 
policy, irrelevant. The dividend irrelevance is supported by contemporary studies conducted by Rashid and Rahman (2008) and Kamyabi and Nazemi (2014).

Dividend relevance or irrelevance have been thus far been discussed as being relevant or not to share prices. However, an investor invests with the expectation that the investment will make a profit. Such investment decisions are made by considering risks attached to the prospected investment. Risk is defined as the possibility that the expected outcome will differ from the actual outcome (Els et al. 2015). As such, the way share prices increase or decrease is of special interest to investors. This movement in share prices is defined as share price volatility and high volatility indicates higher risk attached to the shares (Hashemijoo, Ardekani \& Younesi 2012).

The impact of dividend policy on share price volatility is therefore an important consideration for the investment decision of investors. Baskin (1989) was first to propose and investigate the link between share price volatility and dividend policy. Many academics thereafter applied his framework in an attempt to prove a relevant link between dividend policy and share price volatility, in studies as recent as 2018. The literature from previous studies is discussed in more depth under the 'Literature Review' section.

\section{Research purpose and objective}

Whether or not dividend policy has a measurable influence on long-term share price movement, the 'dividend puzzle', as Black (1976) referred to it, remains a question that has not been answered conclusively. Lintner's model proposing a direct correlation between dividend payout and the market value of a company's share has been proven and, according to Wolmarans (2003), widely refuted. Actual issues such as taxes, market friction and others make it difficult to prove M\&M's proposition as universally true. Share price volatility as a measurement of risk is relevant to an investor's decision when purchasing shares. If a company can reduce the risk perceived by share price volatility through structuring the dividend policy in a certain way, such a company's shares will become more attractive and gain higher investment value.

The objective of this study is to establish whether an association exists between share price volatility and dividend policy for shares trading on the Johannesburg Stock Exchange Limited (JSE) Top 40 for the period 2007-2016. Panel data analysis is employed to determine the relationship between the share price volatility and dividend policy. Additional control variables are included to create a holistic picture of the relationship between share price volatility and dividend policy. The control variables will be discussed under the 'Methodology' section.

\section{Literature review}

Some pertinent factors concerning the theories and sentiments of whether dividend policy actually influences share price movements are identified. These theories aim to justify or disprove the association between share price movements and dividend policy; they are discussed in the following.

\section{Behavioural finance}

There are many factors related to investors' sentiment regarding dividend policy and whether this sentiment actually influences the price of a share (Baker \& Wurgler 2006). Although M\&M (1961) regard dividends and capital growth in share value as equal, Shefrin and Statman (1984) argue that they are not. Without taking the effects of taxation into account, Shefrin and Statman (1984) believe that investors will almost always choose to invest in a share that will provide dividends over capital growth. Apart from the fact that investors believe that dividends declared are an indication of management's expectation of future earnings, behavioural finance indicates that investors prefer cash returns generated by dividends instead of having to liquidate shares to realise returns that are capital growth (Shefrin \& Statman 1984). Jain (2007) supports this notion but limits this behaviour to individuals investing in shares. This desire is despite the fact that the dividends will possibly come at a higher cost because of taxes and other related factors, which may not always follow a logical course of action, as detailed in the following.

Investors typically believe that it is better not to initiate transactions on their own accord by selling shares for cash but prefer to spend money that is scheduled to be paid in the form of dividends (Michaely, Thaler \& Wolmack 1995). This behavioural action is what Shefrin and Statman (1984) label as 'regret aversion'. Another behavioural trait that is likely to make investors choose dividends over capital growth is that investors prefer the certainty of dividends over the uncertainty of share prices (Shefrin \& Statman 1984). Supporting this notion, Fuller and Goldstein (2003) find that companies that pay regular dividends outperform others in depressed markets, which could indicate that investors prefer the certainty of the dividend in hand, rather than have the return capitalised in the share. Such decisions are based on psychological factors instead of logical factors such as cash flow and taxes (Michaely et al. 1995).

\section{Dividends as informational value}

Apart from the behavioural traits mentioned previously, investors believe that dividend declarations pose informational value. The declaration of dividends is most notably linked to signalling theory, agency theory and clientele theory.

\section{Signalling theory}

Investors believe that management can convey information through the dividends that are declared by the company (Bhana 2007; Erasmus 2013; Wolmarans 2000). Easterbrook (1984) discounts the value of the signalling effect, referring to the information conveyed through dividends as vague and therefore not relevant. 
According to Gordon (1959:101) dividends can signal to investors that the company is trading successfully on its equity, experiencing 'an increase in return on investment'. Most importantly, dividends signal management's expectation of the growth of the company's retained earnings. Dividends declared can be a powerful tool to communicate the future prospects and growth projections that a company may be aspiring to. Asquith and Mullins (1983) argue that when dividends are declared, it conveys a strong signal that the company has cash available. This theory also included the informational value that managers possess over the free cash flow system (Gugler \& Yurtoglu 2003).

In contrast to the signalling theory, the efficient market hypothesis (EMH) of Fama (1970) stated that the price of a share already includes all information available and that all information is equally available to all investors and shareholders (Bartlett et al. 2014). The EMH thus renders the dividend relevance theory, such as signalling, irrelevant, because it is theorised that all information is readily available and dividends could not be used as a tool to signal expected performance to investors. However, dividend yield is believed to influence share prices when applying the EMH (Malkiel 2005). In addition, Malkiel (2003) believes that a market will never be fully efficient and there is always some information that is not immediately included in the price of a share. It is therefore possible, even in an efficient market, that dividends could have informational value and result in share price volatility.

\section{Agency theory}

Because the main financial purpose of a company is to maximise shareholders' wealth, surplus cash should be invested into 'value-creating investment opportunities' (Erasmus 2013:16). Investments that create long-term value can either be achieved by reinvesting surplus cash back into the company or by paying it out as dividends. This decision should be based on the principle of maximising shareholders' wealth (Mouton \& Smith 2016).

Should there be a question as to whether the surplus cash is going to be invested into value-creating investments or mismanaged by managers for their own gain, investors would prefer to have any surplus cash paid to them in the form of dividends. Dividends are preferable to having the surplus reinvested in the company at the manager's own discretion at the risk of potential mismanagement of funds (Erasmus 2013; Firer, Gilbert \& Maytham 2008). Companies that follow this 'as and when' approach in the payout of surplus cash through dividends should be aware of the expectations and messages it creates for the investors (Erasmus 2013).

\section{Clientele theory}

Miller and Modigliani (1961) introduced the concept of the clientele effect as a market imperfection, illustrated by investors not behaving rationally. The clientele effect manifests when investors are drawn to a specific share as a result of the need of the investors. Different investor needs will attract investors to shares that declare regular dividends or shares that rather focus on capital growth (Erasmus 2013; Michaely et al. 1995; Miller \& Modigliani 1961; Wolmarans 2003). Certain investors are reliant on regular dividend payouts in order to sustain their needs. As a result, the nature and expectation of investors need to be carefully considered by the company in its objective of creating shareholder value and determining the dividend policy.

\section{Company perspective}

Dividend policy is noted as an important decision for a company (Brav et al. 2003). Brav et al. (2003) conducted interviews with chief financial officers and treasurers and found that companies consider dividend policy to be very important, especially taking into account the aforementioned theories. Companies will try to avoid increasing or decreasing the dividends paid year on year so as not to send the wrong signal to investors. Consistency is so important that the majority of the individuals interviewed said that the company would rather consider taking out a loan or leveraging their borrowing facilities than decreasing dividends.

Firer et al. (2008) surveyed directors of South African (SA) companies and found that the managers are conscious of the signalling effect that dividends hold for investors, although they do not use this often to convey messages to the public. It was further found that SA managers are cautious when setting dividend policy as they prefer not to have to implement a dividend reduction in future (Firer et al. 2008) and that they are wary of the signalling effect. This is consistent with the findings of Brav et al. (2003) stated previously.

\section{Research conducted on dividend policy and investor preference}

Wolmarans (2000) investigated whether or not companies' future returns can in fact be estimated, or predicted, based on dividends declared (using the dividend yield) or the earnings yield. It was found that the dividend yield could not be used to predict 'which group of share is most likely to perform the best during the following year' (Wolmarans 2000:244), and that earnings yield could more accurately be used as a 'ranking method' (Wolmarans 2000:229) to determine future earnings. In 2003, Wolmarans tested South African companies against the Lintner model and found that it could not accurately explain a link between share value and dividend policy.

Bhana (1998) investigated the reaction of share prices on the JSE Limited when special dividends were declared. It was found that the share price reaction to special dividend declarations was positive.

Asquith and Mullins (1983) investigated the effect of dividend increases, or first dividend payments of a company, on the share price of a company. They found that the share price 
increased when either of the two events occurred, which in turn supports the notion of information signalling.

When investigating what motivates companies to declare dividends, Denis and Osobov (2008) found that companies that display characteristics of larger companies, having higher profitability or possible growth, are more likely to declare dividends than companies that do not share these traits. They also concluded that the signalling effect and clientele effect do not influence firms' decisions to pay dividends.

Erasmus (2013) researched the influence of the amount as well as the stability of dividend payments on share returns. It was found that the amount and stability of the dividends paid have a definite influence on the share return.

All the studies reported indicated conflicting results with relation to the influence of dividends and dividend policy on the price of a share. Both the dividend payments and price of the share contribute to the maximisation of wealth for shareholders. As mentioned in the introduction, the minimisation of risk is also a critical factor when investigating shareholders' wealth maximisation. It is therefore imperative that share price volatility as an indication of risk also be considered.

Share price volatility is regarded as 'a benchmark for measuring risk' (Hashemijoo et al. 2012:112). Hashemijoo et al. (2012) researched whether or not dividend policy and the payout ratio have an effect on share price volatility. Hashemijoo et al. (2012) found a negative relationship between share price volatility and dividend yield. Similarly, negative relationships were found between share price volatility and dividend policy by Zainudin, Mahdzan and Yet (2018).

Contrary to these results, Kamyabi and Nazemi (2014) and Kenyoru, Kundu and Kibiwott (2013) found a positive relationship between share price volatility and dividend policy. Ilaboya and Aggreh (2013) could only establish a significant positive relationship between dividend yield and share price volatility and were unable to establish a significant relationship between dividend payout and share price volatility. Rashid and Rahman (2008) could not establish any relationship between share price volatility and dividend policy. The aforementioned studies were all conducted on companies with developing markets, similar to that of the South African market.

In South Africa, an unpublished dissertation prepared by Umwari (2015) indicated a relationship between dividend policy and share price volatility. The sample included all companies identified on the Top 40, even if the company did not declare any dividends.

As can be seen from the results of these studies, conducted in developing markets similar to the South African market, the dividend puzzle remains and the influence of dividend policy on share price volatility is inconclusive. To clarify the relationship in the South African market, another investigation is warranted to substantiate or refute current research results on how much share price volatility is linked to dividend policy.

In order to achieve the objective of this study, volatility of share price and whether or not dividend policy influences the volatility of a company's share price were considered. Both the share price and the volatility of the share price of a company are key drivers in the market capitalisation of companies that also encapsulate shareholder wealth. This study therefore aims to illustrate the impact of dividends, if any, on total shareholder wealth.

\section{Research design Research approach}

A deductive research approach was used for this study, testing existing theory based on that of Hashemijoo et al. (2012), who applied the theoretical framework of Baskin (1989).

\section{Research method}

This study was completed using a quantitative research method. Companies were selected using non-random sampling from the Top 40 companies listed on the JSE Limited's Main Board. The Top 40 constituents included in the sample were the Financial Times Stock Exchange/JSE Top 40 listed by indicative index weight at closing on 30 June 2017. The Top 40 companies were identified as the 40 companies that had the highest market capitalisation on the market (JSE Limited, n.d). Market capitalisation is an indication of growth in the company and the expected future growth and value of the company, which in turn displays a value allocated to the company by the investors.

The data required was extracted for the 10-year period from 2007 to 2016 using the online database McGregor BFA. Companies that did not declare dividends during the 10-year period were eliminated for the study and a total of 33 companies were included in the final data set. The data was analysed using the statistical program EViews, version 9.0.

The list of companies is presented in Appendix 1.

\section{Research instrument and model specification}

Statistical modelling was used for this study according to the approach specified by Baskin (1989), who proposed the question of dividend policy having an influence on share price volatility. Baskin (1989) used ordinary least squared regression in his analysis. Panel data analysis was, however, identified as the appropriate research instrument for this study. Panel data analysis allows for analysis over time and taking into account the differences between the companies in the sample (Brooks 2008). The panel data analysis is supplemented by correlation analysis. 
The panel data regression model is set out as follows (Brooks 2008:487):

$Y_{i t}=\alpha+\beta x_{i t}+\mu_{i t}$

The applicable equation for the regression model with the control variables for this study was stated as follows:

$$
\begin{gathered}
P_{-} \text {vol }_{i t}=\alpha+\beta d_{- \text {yield }_{i t}}+\beta \text { payout }_{i t}+ \\
\beta \text { CoSize }_{i t}+\beta E_{-} \text {vol }_{i t}+\beta \text { Lev }_{i t}+ \\
\beta \text { AssetGrowth }_{i t}+\mu_{i t}
\end{gathered}
$$

where:

$i=$ cross-sectional element

$t=$ time element

P_vol $=$ share price volatility

D_yield $=$ dividend yield

Payout $=$ dividend payout ratio

CoSize $=$ company size

E_vol = earnings volatility

Lev $=$ leverage

Asset Growth $=$ change in assets

$\mu=$ the error term.

Equation 2 sets out to test the impact of dividend policy on share price volatility, controlling for specific variables that were identified as having a possible impact on share price volatility. The null hypothesis was that the relationship between share price volatility and dividend policy was insignificant. Dividend policy was measured by the two variables: dividend yield and dividend policy. Therefore, the associations between share price volatility and dividend yield as well as between share price volatility and dividend payout ratio were analysed using panel data regression analysis. The variables for the regression equation were calculated as illustrated in the following.

\section{Variables}

\section{Dependent variable}

Share price volatility was the dependent variable. It was calculated for each company individually as per the formula suggested by Baskin (1989) with adjustments for using panel data analysis instead of stacked ordinary least squared regression analysis: [(highest share price - lowest share price) / (highest share price + lowest share price) / 2$]^{2}$

\section{Independent variables}

Main variables: Dividend yield partly represented dividend policy. Dividend yield is the percentage dividends paid in relation to the current share price. Dividend yield was the first independent variable, and the dividend yield ratio was collected for each company.

The dividend payout ratio contributed to dividend policy. The payout ratio represented the dividend decision, in which the percentage of earnings was paid out as dividends. The payout ratio was the second independent variable and was calculated by dividing the earnings per share by the dividend per share.
Control variables: There are many factors, apart from dividend policy, that could possibly have an impact on share price volatility. Therefore, the inclusion of control variables was warranted. The control variables were company size, earnings volatility, leverage and change in assets. The four control variables were included in accordance with the initial study by Baskin (1989). Therefore, as the name describes, the control variables were included as a control measure, and the purpose was not to determine and interpret the association of these variables on share price volatility. The association of each control variable with share price volatility will be briefly reported but the focus remained on the relationship between dividend policy and share price volatility. Table 1 indicates how each control variable was calculated.

\section{Research procedure and ethical considerations}

Secondary data was collected from BFA McGregor, a reputable research platform. The data was reworked according to the formulas stated in the previous section. Statistical analysis was performed using correlation analysis and panel data regression analysis.

The data was gathered objectively according to the guidelines set by the original study (Baskin 1989) and subsequent studies (Hashemijoo et al. 2012; Ilaboya \& Aggreh 2013; Kamyabi \& Nazemi 2014, to name a few). The results of this study are limited to companies that paid a dividend during the sample period. By following the research procedure and the use of numerical data, researcher bias was kept at a minimum.

\section{Statistical analysis}

The correlation analysis is presented in Table 2. It was apparent from the weak correlations that the level of multicollinearity between the explanatory variables was low. This was supported by the results of the correlation between company size and dividend payout, having a correlation of 0.1760 , which was the strongest correlation between the explanatory variables.

Share price volatility and dividend yield resulted in a positive correlation (0.1505), indicating a positive relationship. In addition, a positive relationship was identified between share price volatility and dividend payout with a positive correlation of 0.0207 .

TABLE 1: Proxy for control variables.

\begin{tabular}{ll}
\hline Control variables & Formula \\
\hline Company size (CoSize) & Ln(Market capitalisation) \\
Earnings volatility (E_vol) & $\sqrt[2]{\text { EBIT : Total Assets - avg EBIT })^{\wedge} 2}$ \\
Leverage (Leverage) & Leverage ratio \\
Growth in assets (AssetGrowth) & $\begin{array}{l}\text { Change in Total Assets at the end of the year/Total } \\
\text { Assets at the beginning of the year }\end{array}$ \\
\hline
\end{tabular}

Source: Baskin, J., 1989, 'Dividend policy and the volatility of common stocks', The Journal of Portfolio Management 15(3), 19-25. https://doi.org/10.3905/jpm.1989.409203, and author's own work

EBIT, Earnings before interest and tax. 
TABLE 2: Correlation analysis.

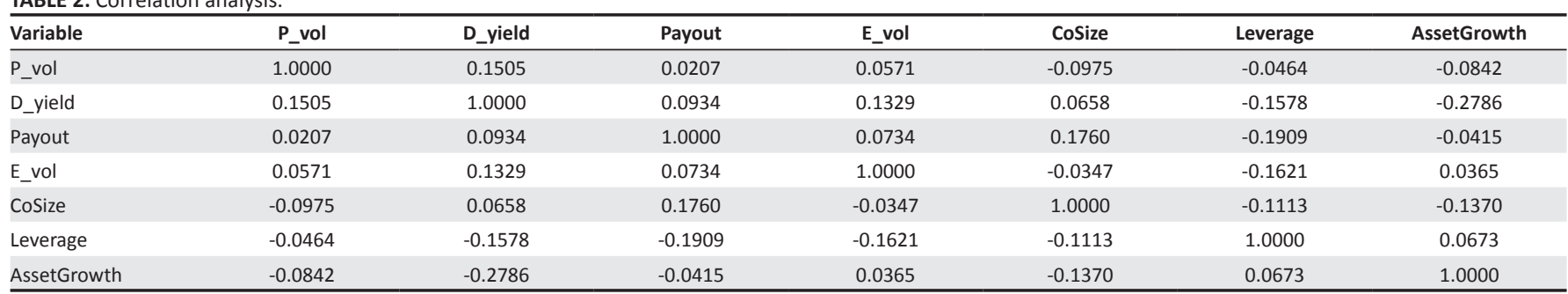

Source: Eviews results

P_vol, share price volatility; D_yield, dividend yield; Payout, dividend payout ratio; E_vol, earnings volatility; CoSize, company size.

TABLE 3: Pooled model.

\begin{tabular}{lcl}
\hline Variable & Coefficient & Probability \\
\hline D_YIELD & 0.010985 & $0.0248^{* * *}$ \\
PAYOUT & 0.005888 & 0.7271 \\
E_VOL & 0.113952 & 0.5651 \\
COSIZE & -0.026900 & $0.0334^{* *}$ \\
LEVERAGE & -0.025338 & 0.6489 \\
ASSETGROWTH & -0.069383 & 0.2745 \\
C & 0.885496 & $0.0059^{* * *}$ \\
\hline
\end{tabular}

Source: Eviews results

Note: Adjusted $R$-squared $=0.022248 ;$ Prob $(F$-statistic $)=0.038605 * *$

D_YIELD, dividend yield; PAYOUT, dividend payout ratio; E_VOL, earnings volatility; COSIZE, company size; AssetGrowth, Growth in company's assets.

$*, * *, * * *$ Significance levels of $10 \%, 5 \%$ and $1 \%$, respectively

The regression for panel data analysis was analysed to account for an association between share price volatility and dividend policy. The results of the three panel data regression models - pooled model, fixed effects model and random effects model - are discussed in the following.

The pooled model, also known as the stacked ordinary least squared model (Brooks 2008), assumes that there is homogeneity between the companies included in this study. The results (see Table 3) of the coefficients (0.010985 and 0.005888) indicated a positive association between share price volatility and both dividend yield and dividend payout, respectively. The results indicated a significant association between share price volatility and dividend yield at the $95 \%$ confidence level $(p=0.0248)$ and an insignificant association between share price volatility and dividend payout $(p=0.7271)$.

The adjusted $R$-squared was reported at $2.22 \%$ with a $p$-value of 0.0386 . This indicated that the explanatory variables have explanatory power over share price volatility; however, the low $R$-squared indicates that all of the explanatory variables jointly have a $2.22 \%$ explanatory power over share price volatility. This result was expected because the companies included in the sample were from different industries. The fixed effects model and random effects model were then regressed in order to determine a more suitable model to explain the association between share price volatility and dividend policy.

The fixed effects model accounts for heterogeneity between the companies included in the sample (Mouton \& Smith 2016). The results of the fixed effect model in Table 4 indicated a positive relationship between share price volatility and dividend yield, as well as share price volatility and dividend
TABLE 4: Fixed effects model.

\begin{tabular}{lll}
\hline Variable & Coefficient & Probability \\
\hline D_YIELD & 0.018745 & $0.0017^{* * *}$ \\
PAYOUT & 0.005426 & 0.7915 \\
E_VOL & 0.152805 & 0.6212 \\
COSIZE & -0.081138 & $0.0002^{* * *}$ \\
LEVERAGE & 0.151520 & 0.2245 \\
ASSETGROWTH & -0.059958 & 0.3877 \\
C & 2.107953 & $0.0001^{* * *}$ \\
\hline
\end{tabular}

Source: Eviews results

Note: Adjusted $R$-squared $=0.129409 ;$ Prob $(F$-statistic $)=0.000068 * * *$.

D_YIELD, dividend yield; PAYOUT, dividend payout ratio; E_VOL, earnings volatility; COSIZE, company size; AssetGrowth, Growth in company's assets.

$*, * *, * * *$ Significance levels of $10 \%, 5 \%$ and $1 \%$, respectively.

TABLE 5: Redundant fixed effects test.

\begin{tabular}{lll}
\hline Effects test & Statistic & Probability \\
\hline Cross-section $F$ & 2.24244 & $0.0003 * * *$ \\
Cross-section chi-square & 72.7362 & $0.0001 * * *$ \\
\hline Source: Eviews results & \\
$*, * *, * * *$ Significance level of $10 \%, 5 \%$ and $1 \%$, respectively. &
\end{tabular}

payout, with coefficients of 0.018745 and 0.005426 , respectively. Similar to the pooled model, the results indicated that dividend yield had a significant association with share price volatility. This association is at the $99 \%$ confidence level with a $p$-value of 0.0017 , contrary to the $95 \%$ confidence level of the pooled model. The dividend payout had an insignificant association with share price volatility, with a $p$-value of 0.7915 . The adjusted $R$-squared value indicated that $12.95 \%$ of the explanatory variables jointly explain a change in share price volatility. This $R$-squared value was higher than that of the pooled model $(2.22 \%)$. The $p$-value indicated that the explanatory power of all the variables was significant at the $99 \%$ confidence level.

To test whether the fixed effects model would better explain the association between share price volatility and dividend policy, the redundant fixed effects test was conducted (Table 5). The test indicated that the differences between companies were relevant to the explanation of the objective of this study at the $99 \%$ confidence level with significant $p$-values of the cross-section $F(0.0003)$ and the cross-section chi-square (0.0001). The fixed effects were therefore not redundant but significant in identifying the association between share price volatility and dividend policy.

The redundant fixed effects test proved that the heterogeneity was significant for the panel regression, and therefore the random effects model needed to be regressed. A random 
TABLE 6: Random effects model.

\begin{tabular}{lll}
\hline Variable & Coefficient & Probability \\
\hline D_YIELD & 0.014294 & $0.0050^{* * *}$ \\
PAYOUT & 0.005797 & 0.7427 \\
E_VOL & 0.104768 & 0.6371 \\
COSIZE & -0.038869 & $0.0072^{* * *}$ \\
LEVERAGE & -0.006663 & 0.9207 \\
ASSETGROWTH & -0.058860 & 0.3545 \\
C & 1.161238 & $0.0016^{* * *}$ \\
\hline
\end{tabular}

Source: Eviews results

Note: Adjusted $R$-squared $=0.035760 ;$ Prob $(F$-statistic $)=0.006709 * * *$.

D_YIELD, dividend yield; PAYOUT, dividend payout ratio; E_VOL, earnings volatility; COSIZE, company size.

$*, * *, * * *$ Significance level of $10 \%, 5 \%$ and $1 \%$, respectively.

TABLE 7: Hausman test.

\begin{tabular}{lc}
\hline Variable & Probability \\
\hline Cross-section random & $0.0151^{* *}$ \\
\hline
\end{tabular}

Source: Eviews results

$* *$, Significance level of $5 \%$.

effects model indicates that the heterogeneity effects between companies are at random and will be captured in the error component of the regression (Brooks 2008).

The results of the random effects model (Table 6) indicated that both dividend yield and dividend payout had a positive relationship with share price volatility, with coefficients of 0.014294 and 0.005797 , respectively. Similar to the results from the fixed effects model, the dividend yield was identified as having a significant association with share price volatility at the $99 \%$ confidence level with a $p$-value of 0.005 . Dividend payout had an insignificant association with share price volatility ( $p=0.7427)$. The adjusted $R$-squared value indicated a $3.58 \%$ explanatory power of the variables combined over share price volatility. This model is significant at the $99 \%$ confidence level with a $p$-value of 0.0067 .

To determine the best model between the fixed effects model and the random effects model, the Hausman test was conducted. The results of the Hausman test in Table 7 indicated that the fixed effect model is more appropriate to use when explaining the association between share price volatility and dividend policy. This was apparent from the cross-section $p$-value of 0.0151 , which indicated that the random effects model was not appropriate in explaining the association. The result of the Hausman test indicated that the fixed effects model was more appropriate than the random effects model to determine the association between share price volatility and dividend policy. Furthermore, the recommendation of using the fixed effects model was substantiated, with the adjusted $R$-squared of the fixed effects model being much higher than the pooled or random effects models.

\section{Discussion}

\section{Outline of the results}

Panel data analysis dictates the use of three models in order to find the most appropriate model for explaining the association between share price volatility and dividend policy. From the preceding statistical analysis, the fixed effects model (Table 4) was identified as the ideal model to use in the interpretation of the results. According to the specification of the fixed effects model, the differences between the companies were therefore relevant and were included in the model.

\section{Share price volatility and dividend policy}

The results indicated that dividend policy was relevant to share price volatility because dividend yield, as part of dividend policy, was proved to have a significant and positive association with share price volatility. This indicated that shareholders and investors were mindful of the dividend amount paid in relation to share prices, indicating that the signalling theory could be relevant for these companies listed on the JSE Main Board.

Even though dividend payout did not have a significant association with share price volatility, the result was not surprising. The companies in this sample were identified as the top 40 companies based on their market capitalisation. Therefore, for these big and established companies, it was accepted that shareholders would have confidence in the management and distribution of earnings of these companies. Thus, the agency theory does not appear to be relevant. Risk as portrayed in share price volatility has been proved to be evident when the dividends declared changes accordingly with share price changes.

The role of the control variables was to account for additional factors that could influence or have an association with the share price volatility of a company. These variables were identified by Baskin (1989) and are included in this study accordingly. The control variables are therefore included to provide support for the results of the explanatory power of dividend policy on share price volatility. Therefore, the results of the control variables are not discussed in depth but will only be mentioned.

It was surprising that company size was the only control variable that had a significant association with share price volatility. The coefficient of the fixed effects model indicated a negative association, and it was substantiated by the correlation matrix. The remaining control variables - earnings volatility, leverage and asset growth - were found to be insignificant to share price volatility. With the majority of the control variables found to be insignificant, future research can focus on identifying additional factors within a company that could influence risk reflected in share price volatility. This study should then be repeated to determine if dividend policy is as significant as determined in this study.

It was apparent from the results that dividends are relevant to investors, supporting Gordon (1959). Contrary to Jain (2007) on behavioural finance, the results indicated that the investors did not have any preference for dividends over growth within the company for the sample companies. The reported significance of dividend yield supported 
Malkiel (2005), who stated that dividend yield could influence changes in share prices, and Erasmus (2013), who stated that stable and consistent dividends are relevant to share returns. In addition, the significant dividend yield supported the notion of Fuller and Goldstein (2003) that investors preferred a consistent and regular dividend policy. A consistent and regular dividend policy indicated that the signalling theory was important.

The insignificant finding of the dividend payout supported the notion of Gordon (1959) that investors require the adequate distribution of earnings between dividend and retaining earnings for company growth opportunities. Consequently, the results of this study refuted the agency theory and indicated confidence from investors that management will apply any surplus earnings to the benefit of creating shareholders' wealth.

The results were in support of Erasmus (2013), who was able to establish an influence between stable dividends and share prices. In addition, the findings of this study supported the findings of Firer et al. (2008) that the managers were aiming for a consistent dividend policy. Having a consistent dividend policy compared to a dividend policy where dividend payments are related to earnings could decrease the risk as indicated in the share price volatility.

The results of this study are consistent with the unpublished dissertation of Umwari (2015), who found a relationship between share price volatility and dividend policy. This consistency supports the reliability and validity of the method of analysis and the results, because the sample and sample period of this study differ from that of Umwari (2015).

\section{Practical implications}

This study proved that an association exists between dividend policy and share price volatility. The dividend policy decision is in the control of the management of the company, and therefore an informed dividend decision could decrease the risk associated with share price volatility.

The results of the study indicated that a company should aim for a consistent dividend policy, evident from the positive association between dividend yield and share price volatility. However, the reported insignificant association between dividend payout and share price volatility provided important information for the management team of a company. The insignificance of the dividend payout indicated that management can also structure the dividend policy to enable the company to reinvest portions of the earnings without having to adjust the dividend payment proportionately to earnings.

\section{Limitations and recommendations}

A possible limitation to this study is that the sample size might be too small. It is suggested that, for further research, companies of all market capitalisations be included and not only those with the biggest market capitalisation. It is recommended that this analysis be repeated on all dividendpaying companies listed on the JSE to determine if a consistent result can be identified applicable to all companies.

In further research, share price volatility of companies from different industries can be compared to determine whether dividend yield and dividend payout have a stronger influence in share price volatility of different sectors.

\section{Conclusion}

Dividend policy and drivers of dividend policy decisions have been researched in the past. The main focus of previous research was on what companies are currently doing with their dividend policy and the motivation of the dividend policy decision. However, few researchers have been able to identify a recommendation for managers of a company regarding the long-term implication of share price volatility from their dividend policy decisions. This study aimed to identify whether dividend policy decisions have an impact for shareholders and investors, reflected in share price volatility.

Dividend yield and dividend payout ratio together were used as indicators for dividend policy. Consequently, the association of both dividend yield and the payout ratio on share price volatility was investigated. Control variables were included to account for additional factors that could have an impact on share price volatility. Dividend policy was expected to have a negative impact on share price volatility, as investors are expected to prefer safe and conservative investments (Baker \& Wurgler 2006) and will therefore favour companies paying regular dividends, which should have a stable share price in the long term.

A positive correlation between share price volatility and dividend yield as well as share price volatility and dividend payout ratio was established and was consistent with the expectations. The weak correlation between share price volatility and dividend yield as well as share price volatility and dividend payout ratio was enforced by the findings of the regression analysis.

The results of the panel data analysis indicated, firstly, that the fixed effects model was most appropriate in the regression analysis. Secondly, an association between share price volatility and dividend policy was established, with dividend yield found to have a significant association and dividend payout found to have an insignificant association with share price volatility.

The results indicated that the dividends were relevant to investors, indicating that the signalling theory was relevant, and investors believed in information being transferred in the dividend policy decision. However, an agency problem was indicated as irrelevant to this sample of companies. The results indicated that the company's management could make dividend policy decisions for optimum growth within 
the company and wealth maximisation for shareholders, taking into account that dividends in relation to share price are deemed as a signalling tool to investors. In conclusion, risk found in share price volatility can and should be mitigated through dividend policy.

\section{Acknowledgements}

The author wishes to acknowledge and thank Mr Jean Struweg for his belief in this topic and his encouragement to publish this article.

\section{Competing interests}

The author declares that she has no financial or personal relationships that may have inappropriately influenced her in writing this article.

\section{References}

Asquith, P. \& Mullins, D.W., 1983, 'The impact of initiating dividend payment on shareholder' wealth', The Journal of Business 56(1), 77-96. https://doi. org/10.1086/296187

Baker, M. \& Wurgler, J., 2006, 'Investor sentiment in the stock market', Journal of Economic Perspectives 21, 129-151. https://doi.org/10.1257/jep.21.2.129

Bartlett, G., Beech, G., De Hart, F., De Jager, P., De Lange, J., Erasmus, P. et al., 2014 Financial management. Turning theory into practice, Oxford University Press, Southern Africa.

Baskin, J., 1989, 'Dividend policy and the volatility of common stocks', The Journal of Portfolio Management 15(3), 19-25. https://doi.org/10.3905/jpm.1989.409203

Bhana, N., 1998, 'The share price reaction on the Johannesburg Stock Exchange for special (extra) dividend announcements', Investment Analysts Journal 47(1), 5-15. https://doi.org/10.1080/10293523.1998.11082382

Bhana, N., 2007, 'The market reaction to open market share repurchases announcements: The South African experience', Investment Analysts Journal 65, 25-36. https://doi.org/10.1080/10293523.2007.11082486

Black, F., 1976, 'The dividend puzzle', The Journal of Portfolio Management 2(2), 5-8. https://doi.org/10.3905/jpm.1976.408558

Brav, A., Graham, J.R., Harvey, C.R. \& Michaely, R., 2005, 'Payout policy in the 21st century', Journal of Financial Economics 77, 483-527.

Brooks, C., 2008, Introductory econometrics for finance, 2nd edn., Cambridge University Press, Cambridge.

Denis, D.J. \& Osobov, I., 2008, 'Why do firms pay dividends? International evidence on the determinants of dividend policy', Journal of Financial Economics 89, 62-82. https://doi.org/10.1016/j.jfineco.2007.06.006

Easterbrook, F.H., 1984, Two agency-cost explanations of dividends', The American Economic Review 74(4), 650-659.

Els, G., Van Gaalen, R., Strydom, N.T. \& Beekman, E., 2015, Fundamentals of finance. A practical guide to the world of finance, 6 th edn., Lexis Nexis, South Africa.

Erasmus, P., 2013, 'The influence of dividend yield and dividend stability on share returns: Implications for dividend policy formulation', Journal of Economic and Financial Sciences 6(1), 13-32.

Fama, E.F., 1970, 'Efficient capital markets: A review of theory and empirical work', The Journal of Finance 25(2), 383-417. https://doi.org/10.2307/2325486
Firer, C., Gilbert, E. \& Maytham, A., 2008, 'Dividend policy in South Africa', Investment Analysts Journal 68, 5-20. https://doi.org/10.1080/10293523.2008.11082500

Fuller, K.P. \& Goldstein, M.A., 2003, Dividend policy and market movements, Working Paper, Terry College of Business, University of Georgia viewed n.d., from http:// faculty.babson.edu/goldstein/research/divpapkfmg.pdf

Gordon, M.J., 1959, 'Dividends, earnings, and stock prices', The Review of Economic and Statistics 41(2), 99-105. https://doi.org/10.2307/1927792

Gugler, K. \& Yurtoglu, B., 2003, 'Corporate governance and dividend pay-out in Germany', European Economic Review 47, 731-758. https://doi.org/10.1016/ S0014-2921(02)00291-X

Hashemijoo, M., Ardekani, A.M. \& Younesi, N., 2012, 'The impact of dividend policy on share price volatility in the Malaysian Stock Market', Journal of Business Studies Quarterly 4(1), 111-129.

Ilaboya, O.J. \& Aggreh, M., 2013, 'Dividend policy and share price volatility', Journal of Asian Development 2(2), 109-112.

Jain, R., 2007, 'Institutional and individual investor preferences for dividends and share repurchases', Journal of Economics and Business 59, 406-429. https://doi. org/10.1016/j.jeconbus.2007.04.004

JSE Limited, n.d., viewed 20 May 2015, from https://www.jse.co.za/capital/mainboard

Kamyabi, Y. \& Nazemi, E., 2014, 'Investigating relationship between dividend policy and stock price volatility of firms accepted at Tehran Stock Exchange', Applied Mathematics in Engineering, Management and Technology 2(6), 622-630.

Kenyoru, N.D., Kundu, S.A. \& Kibiwott, L.P., 2013, 'Dividend policy and share price volatility in Kenya', Research Journal of Finance and Accounting 4(6), 115-120.

Lintner, J., 1956, 'Distribution of incomes of corporations among dividends, retained earnings, and taxes', The American Economic Review 46(2), 97-113.

Malkiel, B.G., 2003, 'The efficient market hypothesis and its critics', The Journal of Economics Perspectives 17(1), 59-82. https://doi.org/10.1257/0895330033211 64958

Malkiel, B.G., 2005, 'Reflections on the efficient market hypothesis: 30 years later', The Financial Review 40, 1-9. https://doi.org/10.1111/j.0732-8516.2005.00090.x

Michaely, R., Thaler, R.H. \& Womack, K.L., 1995, 'Price reactions to dividend initiations and omissions: Overreaction or drift', Journal of Finance 50(2), 573-608. https:// doi.org/10.1111/j.1540-6261.1995.tb04796.x

Miller, M.H. \& Modigliani, F., 1961, 'Dividend policy, growth, and the valuation of shares', The Journal of Business 34(4), 411-433. https://doi.org/10.1086/294442

Mouton, M. \& Smith, N., 2016, 'Company determinants of capital structure on the JSE Ltd and the influence of the 2008 financial crisis', Journal of Economic and Financial Sciences 9(3), 789-806. https://doi.org/10.4102/jef.v9i3.71

Rashid, A. \& Rahman, A.Z.M.A., 2008, 'Dividend policy and stock price volatility: Evidence from Bangladesh', Journal of Applied Business and Economics 8(4), 71-81.

Sharenet, n.d., JSE full names and codes, viewed 20 May 2015, from https://www. sharenet.co.za/free/jsenames.phtml?scheme=default

Shefrin, H.M. \& Statman, M., 1984, 'Explaining investor preference for cash dividends', Journal of Financial Economics 13, 253-282. https://doi.org/10.1016/0304 405X(84)90025-4

Umwari, E.L., 2015, 'The impact of dividend yield and dividend pay-out ratios on share price volatility in South Africa', Unpublished (Master's) dissertation, University of Johannesburg, Johannesburg.

Wolmarans, H.P., 2000, 'Does "dividend investing" have value for the South African investor?', Meditari Accountancy Research 8, 229-247. https://doi.org/ 10.1108/10222529200000012

Wolmarans, H.P., 2003, 'Does Lintner's dividend model explain South African dividend payments ?', Meditari Accountancy Research 11, 243-254. https://doi.org/ 10.1108/10222529200300015

Zainudin, R., Mahdzan, N.S. \& Yet, C.H., 2018, 'Dividend policy and stock price volatility of industrial products firms in Malaysia', International Journal of Emerging Markets 13(1), 203-217. https://doi.org/10.1108/IJoEM-09-2016-0250 


\section{Appendix 1}

TABLE 1-A1: List of sample companies used in analysis.

\begin{tabular}{|c|c|}
\hline Share name & Full company name \\
\hline ANGLO & Anglo American Plc \\
\hline ASPEN & Aspen Pharmacare Holdings Ltd \\
\hline B-AFRICA & Barkleys Africa group Ltd \\
\hline BHPBILL & BHP Billiton Plc \\
\hline CAPITEC & Capitec bank holdings Ltd \\
\hline RICHEMONT & Compangie Financiere Richemont SA \\
\hline DISCOVERY & Discovery Ltd \\
\hline FIRSTRAND & Firstrand Ltd \\
\hline GROWPNT & Growthpoint Properties Ltd \\
\hline INTUPLC & Intu Properties PIc \\
\hline INVLTD & Investec Ltd \\
\hline INVPLC & Investec Plc \\
\hline MONDILTD & Mondi Ltd \\
\hline MONDPLC & Mondi Plc \\
\hline MR PRICE & Mr Price Group Ltd \\
\hline MTN GROUP & MTN Group Ltd \\
\hline NASPERS & Naspers Ltd \\
\hline NEDBANK & Nedbank Group Ltd \\
\hline NETCARE & Netcare Ltd \\
\hline OLDMUTUAL & Old Mutual Plc \\
\hline REDEFINE & Redefine Properties Ltd \\
\hline REMGRO & Remgro Ltd \\
\hline RMBH & Rand Merchant Investment Holdings Ltd \\
\hline SANLAM & Sanlam Ltd \\
\hline SAPPI & Sappi Ltd \\
\hline SASOL & Sasol Ltd \\
\hline SHOPRIT & Shoprite Holdings Limited \\
\hline STANBANK & Standardbank Group Ltd \\
\hline STEIN NV & Steinhoff International Holdings N.V. \\
\hline BIDVEST & Bidvest Group \\
\hline TIGBRANDS & Tiger Brands Ltd \\
\hline TRUWTHS & Truworths International Ltd \\
\hline WOOLIES & Woolworths Holdings Ltd \\
\hline
\end{tabular}

Source: Author's own construction, data extracted from https://www.sharenet.co.za/free/ jsenames.phtml?scheme=default 